\title{
A population dynamics approach to the estimation of production of four calanoid copepods in Lindåspollene, western Norway
}

\author{
Dag L. Aksnes, Thorolf Magnesen \\ Department of Marine Biology, University of Bergen, N-5065 Blomsterdalen, Norway
}

\begin{abstract}
Estimates were made of copepod production, based on estimates of recruitment, mortality, development times and individual weight data, and the methodological approach given earlier by Sonntag \& Parslow is further developed. In addition to estimates of cohort production, the present approach includes estimation of daily production in depth and time. The estimation method is applied to abundance data of the copepodids of Pseudocalanus elongatus, Paracalanus parvus, Temora longicornis and Centropages hamatus obtained in Lindåspollene in 1981. Production during June was estimated as $446,252,231$ and $63 \mathrm{mg}$ ash-free dry weight $\mathrm{m}^{-2}$ respectively. Production of $P$. parvus and $C$. hamatus was primarily concentrated in the upper $5 \mathrm{~m}$, while that of $T$. longicornis and $P$. elongatus was located below $5 \mathrm{~m}$ depth. The cohort $\mathrm{P} / \mathrm{B}$ ratios were estimated in the range 2.5 to 6.8 . The daily $\mathrm{P} / \mathrm{B}$ ratios (including data for Calanus finmarchicus) were strongly dependent on the stage of development within the populations, but did not seem to differ much between species.
\end{abstract}

\section{INTRODUCTION}

A population dynamics approach to the estimation of copepod production was recommended by Sonntag \& Parslow (1981). This approach consists essentially of estimating mortality, recruitment, development times and stage-specific weights. Production is then calculated from these estimates. Several methods for estimating recruitment, mortality and development times of copepods have been proposed (Fager 1973, Rigler \& Cooley 1974, Parslow et al. 1979, Lynch 1983, Hairston \& Twombly 1985). Similar methods, applicable to species that have recognizable developmental stages, have been developed in entomology (Richards et al. 1960, Ashford et al. 1970, Manly 1974a, b, 1976 , 1977, Birley 1977, Kempton 1979, Straalen 1982). Such methods may be separated into 2 groups: those where the estimates of population parameters are based upon fitting models to time series of stage frequency observations, and those where the estimates are calculated from certain statistics of the observed stage frequency distributions. Four methods of the first category, termed systems identification techniques, were tested by Parslow et al. (1979) on simulated and observed copepod data, but all 4 methods were found to produce unreliable estimates of mortality. Despite this, Sonntag \& Parslow (1981) found that 2 of these methods, which were based on a method originally given by Manly (1974a), gave reliable estimates of secondary production. In the present paper we use a more recent method (Manly 1977), which belongs to the second category mentioned above. For discussion of this method in comparison to other methods used in cohort analysis see Hairston \& Twombly (1985), Aksnes \& Høisæter (1987) and Hairston et al. (1987). We have included 2 additional parameters in the estimation model that enables time/depth computation of production. The estimation model is applied to stage frequency data of Paracalanus parvus, Pseudocalanus elongatus, Temora longicornis and Centropages hamatus sampled in Lindåspollene, a landlocked fjord in western Norway.

\section{MATERIAL AND METHODS}

Sampling. Zooplankton sampling was carried out during daytime (between 10:00 and 15:00 h) on 7, 10,11, 16, 22 and 29 June 1981 in the central part of Spjeldnesosen, one of the basins in Lindasspollene (Fig. 1). During 10 and 11 June sampling was performed at 10:00, 14:00, 


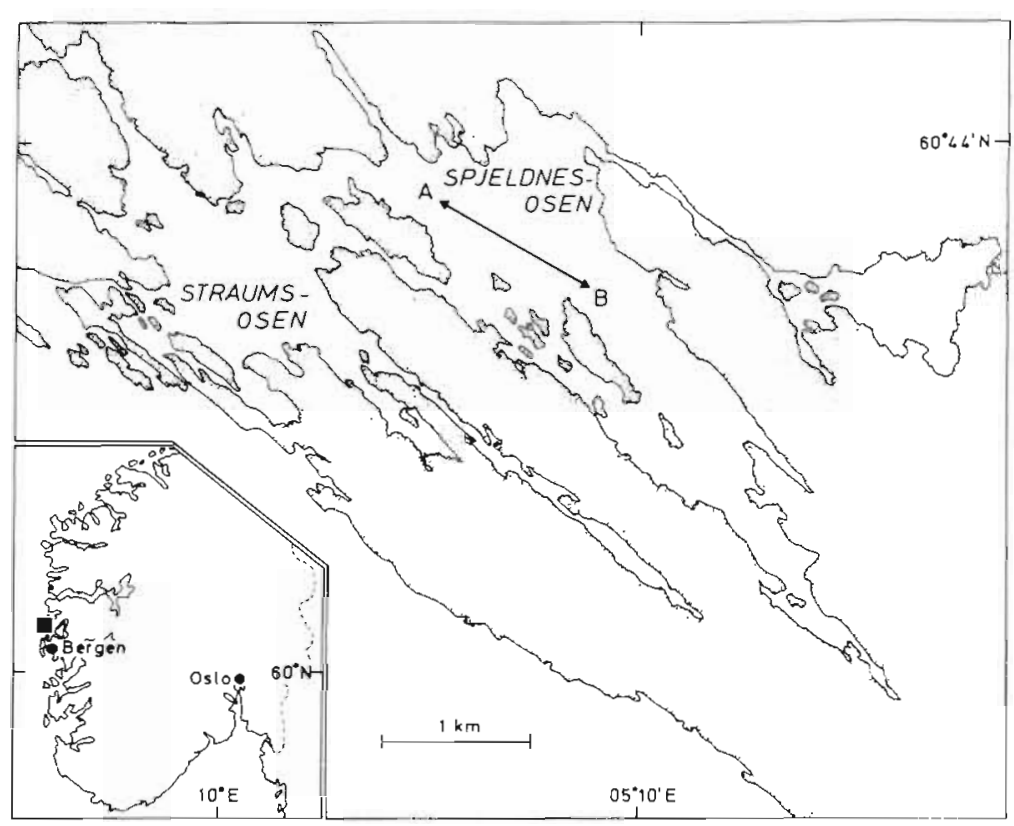

Fig. 1. Sampling location in Lindåspollene, Norway. $A-B$ indicates the cruise track used in the sampling
18:00, 22:00, 00:00, 02:00, 04:00 and 08:00 h. Samples were collected with Clarke-Bumpus plankton samplers equipped with $75 \mu \mathrm{m}$ mesh size nets. The samplers were hauled over a $1 \mathrm{~km}$ distance (Fig. 1) at 0.5,2,5,10,15 and $20 \mathrm{~m}$ depths. The sampling was carried out from $\mathrm{M} / \mathrm{B}$ 'Knurr', a $9 \mathrm{~m}$ motorboat with a $20 \mathrm{hp}$ engine and a hydraulic winch. In the present study only the average abundances (and variances) of the diel sampling on 10 and 11 June are used, while the detailed results of the diel sampling are given by Magnesen et al. (unpubl.). All samples were preserved in $4 \%$ formalin and subsampled with a modified Folsom splitter (Motoda 1959). Usually, $1 / 32$ or $1 / 64$ (range $1 / 8$ to $1 / 256$ ) of the initial sample was examined and the various organisms identified and counted. The calanoid copepods were identified and enumerated according to the 6 copepodid stages. Copepodid Stages I, II and III were combined into one group, Stages IV and V into a second group, and adult males and females into a third group before the population parameters were estimated.

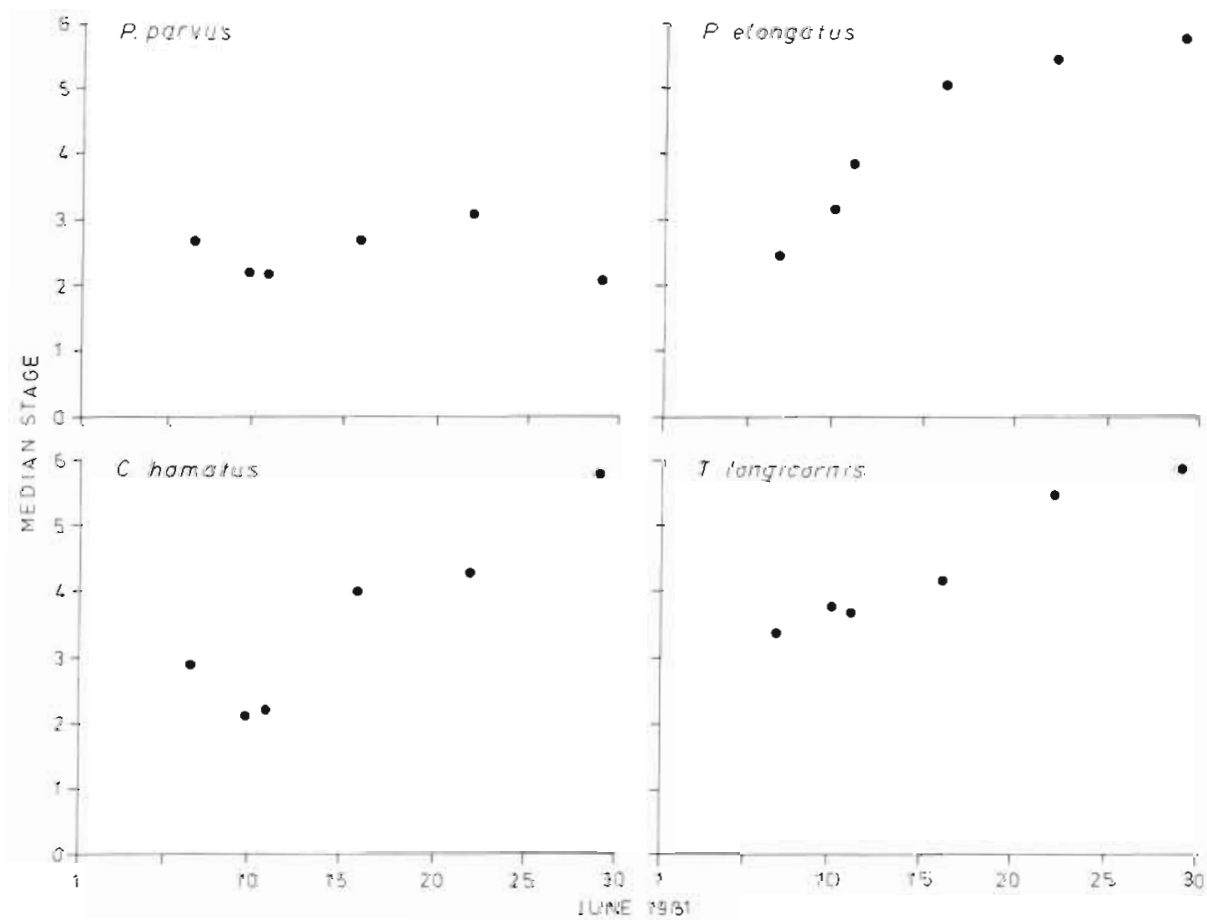

Fig. 2. Paracalanus parvus, Centropages hamatus, Pseudocalanus elongatus and Temora longicornis. Median copepodid stage of the 4 copepod species during the investigation 
Population model. The population model of Manly (1977) is applicable to cohorts with unimodal recruitment:

$$
N_{i}(t)=M_{i} \int_{t-a_{1}}^{t} f_{i}(x) e^{-\theta_{1}(t-x)} d x
$$

where $N_{i}(t)=$ number of individuals in Stage $i$ at Day $t$; $M_{i}, a_{i}$ and $\Theta_{i}=$ no. of recruits, development time (in d), and mortality (daily instantaneous) for the stage under consideration; $f_{i}(x)=$ the normal probability function which is assumed to give the probability of an individual entering the stage at time $x=t$. The mean of $f_{1}(x)$ is denoted $\mu_{n}$, and the standard deviation of $f_{i}(x)$ is denoted $\sigma_{1}$

We have extended Eq. (1) to include the depth dimension:

$$
N_{i}(t, z)=N_{i}(t) h_{i}(z), \quad h_{i}(z)=g_{i}(z)+g_{t}(-z)
$$
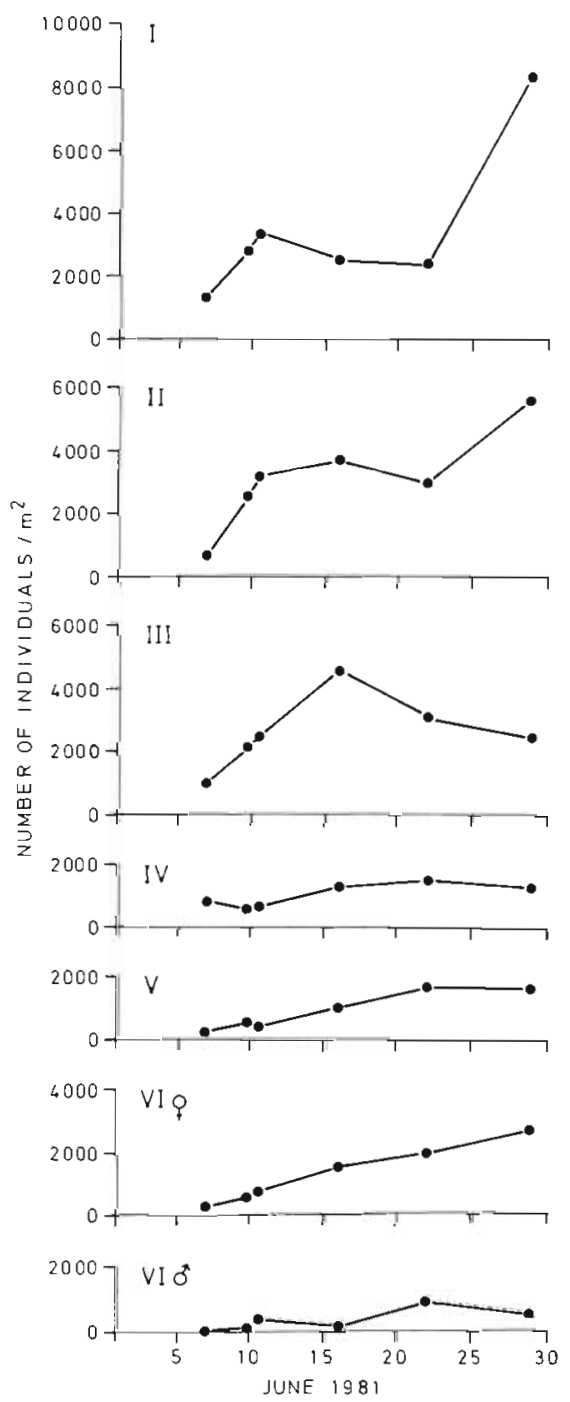

Fig. 3. Paracalanus parvus. Surface-integrated abundances of copepodids where $h_{,}(z)=$ the distribution that describes the recruitment in depth $(z) ; g_{i}(z)$ is the normal frequency distribution with mean $\alpha_{i}$ (mean recruitment depth) and standard deviation $\beta_{i}$ (the spread of recruitment in depth). When the recruitment distribution is located far away from the surface, $h_{i}(z)$ and $g_{i}(z)$ will, from a practical view, be identical. This is not the case when the distribution is located close to the surface. That part of $g_{i}(z)$ which distributes above the sea surface $(z<0)$ is retained below the surface by setting $h_{1}(z)=g_{1}(z)+$ $g_{1}(-z)$

Estimation of population parameters and production. The population parameters $M_{1}, \Theta_{i}, a_{1}, \mu_{i}$ and $\sigma_{i}$ were estimated by the use of the equations given by Manly (1977). This approach is an improvement of the graphical estimation technique presented by Manly (1976). The essential equations for estimation are (Manly 1977):

$$
\begin{aligned}
& w_{1}=A_{1+1} / A_{i} \\
& a_{2}=B_{1+1}-B_{1} \\
& \Theta=-\ln \left(w_{i}\right) / a_{i} \\
& M_{i}=A_{1} \Theta \\
& \mu_{1}=B_{1}-1 / \Theta \\
& \sigma_{i}^{2}=C_{i}-1 / \Theta^{2}
\end{aligned}
$$

where $w_{i}=$ stage-specific survival for Stage $i_{i} A_{i}=$ the estimated area under the combined frequency curve for Stage $i, i+1, \ldots q$ (where $q$ is the final adult stage); $B_{i}$ and $C_{i}$ are the estimated temporal mean and variance of this combined frequency curve. Manly (1977) gives alternative estimation procedures when the data are insufficent (i.e. when the entire life-span is inadequately sampled).

Mortality $(\Theta$, which represents an average mortality for all stages) may be estimated from the decrease in total numbers $\left(N_{\text {tot }}(t)\right)$ after recruitment to copepodid Stage I has ceased (after the disappearance of this stage from the samples):

$$
\Theta=\frac{\ln \left[N_{\text {tot }}\left(t_{1}\right)\right]-\ln \left[N_{\text {tot }}\left(t_{2}\right)\right]}{t_{2}-t_{1}}
$$

where $t_{1}$ and $t_{2}$ represent 2 subsequent dates. This estimate of $\Theta$ may replace the mortality estimate given in Eq. (3a). Additionally, estimates of the development times $\left(a_{i}\right)$ may be obtained from other sources (i.e. laboratory experiments). These parameters may then be eliminated as unknowns in Eqs. (3a).

The mean recruitment depth $\alpha_{i}$ and the standard deviation $\beta_{i}$ were estimated as the mean depth and the standard deviation of the vertical distribution of the stage (or combined stage) under consideration.

Calculated time/depth series of the stage frequencies were obtained by inserting the estimated population parameters into Eq. (2). These calculated time series were compared to the observations. Unlike the 
methods of Manly (1974a) and Parslow et al. (1979), our calculated time series are not fitted to the observations with a curve-fitting procedure. The variance between the abundances obtained at equal depths during the intensive sampling on 10 and 11 June was calculated, and is referred to as 'within observations' variance (Table 2).

The copepodid production of a cohort was estimated by the equation:

$$
P_{\text {con }}=\sum_{i=1}^{q-1}\left(M_{i}-M_{i+1}\right) \omega_{i}+M_{q} \omega_{q}
$$

where $\omega_{j}=$ ash-free dry weight of an individual of Stage $i_{i} q$ denotes the adult stage. Weights of the different copepodid stages were obtained from measurements on late copepodids and adults collected in Lindåspollene (Yen unpubl.) and from measurements published by Harris et al. (1982) and Klein Breteler et al. (1982). The weights of the individual stages were in the range 1 to $21 \mathrm{\mu g}$ ash-free dry weight for the different species. The average deviation between the measurements made on animals collected in Lindåspollene and those of Klein Breteler et al. (1982) was $13 \%$.

The daily production in time and depth was calculated as:

$$
P(t, z)=\sum_{i=1}^{q-1}\left[N_{i}(t, z)+N_{i}(t+1, z)\right]\left(\omega_{i+1}-\omega_{i}\right) / 2 a_{1}
$$

where $N(t, z)$ is given by Eq. (2). The production expressed by Eqs. (4) and (5) represents the production due to the weight increase between stages only. Production associated with molting and egg production is not considered in this paper.

\section{RESULTS}

The median stage values (Fig. 2) increased for Pseudocalanus elongatus, Temora longicornis and Centropages hamatus during the investigation, indicat ing that these populations developed as single cohorts. This was not the case for Paracalanus parvus. The low median stage value on 29 June is explained by the increase in Stages I and II on this date (Fig. 3). This increase in young copepodid stages is interpreted as the appearance of a new cohort.

\section{Population parameters}

Estimates of the population parameters for the combined copepodid Stages I to III, IV to $\mathrm{V}$ and VI are shown in Table 1. Estimated development times for the combined copepodid stages were 6.4, 7.4, 9.2 and $16 \mathrm{~d}$ for Paracalanus parvus, Temora longicornis, Pseudocalanus elongatus and Centropages hamatus respectively. Estimated death rates were in the range 7 to $26 \%$ per day. The lowest mortalities were found for $C$. hamatus and $P$. elongatus which also had the longest development times. Out of a total of 199000 ind. $\mathrm{m}^{-2}$ calanoids that entered the copepodid Stage I, 49000 ind. $\mathrm{m}^{-2}$ were estimated to enter the adult stage.

\section{Abundances: observations and model calculations}

The variances between observations and model calculations, and the variances between the 8 'replicate'

Table 1. Estimates of population parameters; the number of recruits ( $M$ ) to the $1 \mathrm{~m}^{2}$ water column, stage specific survival (w),

\begin{tabular}{|c|c|c|c|c|c|c|}
\hline Species & Stage & $M$ & $w$ & a & $\Theta$ & $1-e^{-\theta}$ \\
\hline Paracalanus parvus Cohort 1 & $\begin{array}{l}\text { I-III } \\
\text { IV-V } \\
\text { VI }\end{array}$ & $\begin{array}{r}63000 \\
35700 \\
9300\end{array}$ & $\begin{array}{l}0.57 \\
0.26\end{array}$ & 6.4 & 0.30 & 0.26 \\
\hline P. parvus Cohort 2 before 29 June & $\begin{array}{l}\text { I-III } \\
\text { IV-V } \\
\text { VI }\end{array}$ & $\begin{array}{r}22000 \\
3000 \\
1300\end{array}$ & \multicolumn{4}{|c|}{ Estimates for Cohort 1 were used } \\
\hline Centropages hamatus & $\begin{array}{l}\text { I-III } \\
\text { IV-V } \\
\text { VI }\end{array}$ & $\begin{array}{l}6300 \\
3500 \\
2000\end{array}$ & $\begin{array}{l}0.55 \\
0.57\end{array}$ & 16.0 & 0.07 & 0.07 \\
\hline Pseudocalanus elongatus & $\begin{array}{l}\text { I-III } \\
\text { IV }-Y \\
\text { VI }\end{array}$ & $\begin{array}{l}59800 \\
34700 \\
21800\end{array}$ & $\begin{array}{l}0.58 \\
0.63\end{array}$ & 9.2 & 0.11 & 0.10 \\
\hline Temora longicornis & $\begin{array}{l}\mathrm{I}-\mathrm{III} \\
\mathrm{IV}-\mathrm{V} \\
\mathrm{VI}\end{array}$ & $\begin{array}{l}48000 \\
27300 \\
15200\end{array}$ & $\begin{array}{l}0.57 \\
0.56\end{array}$ & 7.4 & 0.15 & 0.14 \\
\hline
\end{tabular}
development time (a) in days, and instantaneous mortality $\Theta$ for the combined copepodid stages 
Table 2. Variance within observations obtained from samples taken on 10 and 11 June, compared with variance between observed and model-calculated abundances during 7 to 29 June. Abundances are aggregated into the 3 groups: copepodid Stage I-III, IV-V, and IV. All numbers are multiplied by $10^{-4}$

\begin{tabular}{|c|c|c|c|c|c|c|c|c|}
\hline \multirow{2}{*}{$\begin{array}{l}\text { Combined } \\
\text { copepodid stage }\end{array}$} & \multicolumn{2}{|c|}{ Paracalanus parvus } & \multicolumn{2}{|c|}{ Centropages hamatus } & \multicolumn{2}{|c|}{ Pseudocalanus elongatus } & \multicolumn{2}{|c|}{ Temora longicornis } \\
\hline & Within & Between & Within & Between & Within & Between & Within & Between \\
\hline I-III & 54 & 30 & 9 & 3 & 43 & 80 & 169 & 40 \\
\hline IV-V & 2 & 10 & 1 & 1 & 65 & 152 & 41 & 11 \\
\hline VI & 6 & 26 & 2 & 1 & 7 & 34 & 53 & 30 \\
\hline
\end{tabular}

samples taken on 10 and 11 June, are given in Table 2. Among the 12 groups ( 4 species and 3 combined stages) the variance between model calculations and observations was less than the sampling variance on 5 occasions, equal on 1 , and higher on the remaining 6.

Paracalanus parvus was almost exclusively found at 0.5, 2 and $5 \mathrm{~m}$ depth (Fig. 4). The highest observed abundances for the juveniles of the first cohort were found at $5 \mathrm{~m}$ depth, while adults and the juveniles of the second cohort were found in highest number at 0.5 and $2 \mathrm{~m}$ depth. The model calculations are in fairly good agreement with the observations. The variance between model calculations and observations was almost identical with the variance within observations on 1 occasion, while it was higher on the other 2 (Table 2).

Centropages hamatus was, as Paracalanus parvus, almost exclusively found at 0.5,2 and $5 \mathrm{~m}$ depth (Fig. 5), but with highest abundances at $5 \mathrm{~m}$ depth. Relatively low densities were found for this species throughout the investigation period (less than 900 ind. $\mathrm{m}^{-3}$ ). The model calculations correspond well with the observations (Fig. 5). This is also demonstrated by the lower variance found between model calculations and observations compared to the within-observations variance (Table 2).

Pseudocalanus elongatus juveniles (Fig. 6) were mainly found at $10 \mathrm{~m}$ depth. The older copepodid
Fig. 4. Paracalanus parvus. (A, B) Observed and (C, D) modelcalculated abundances (ind. $\mathrm{m}^{-3}$ ) for $(A, C)$ juvenile copepodids and $(B, D)$ adults
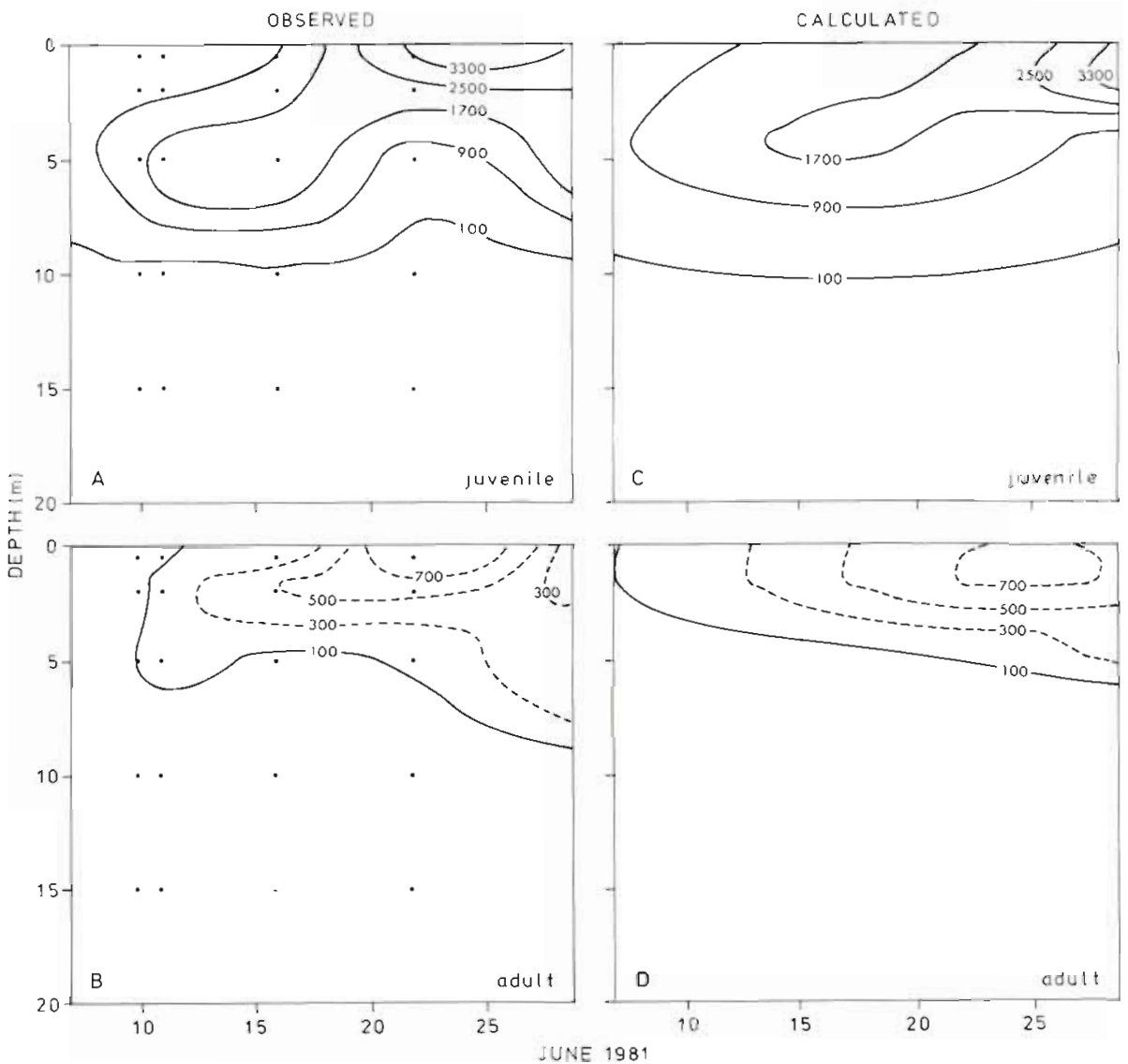

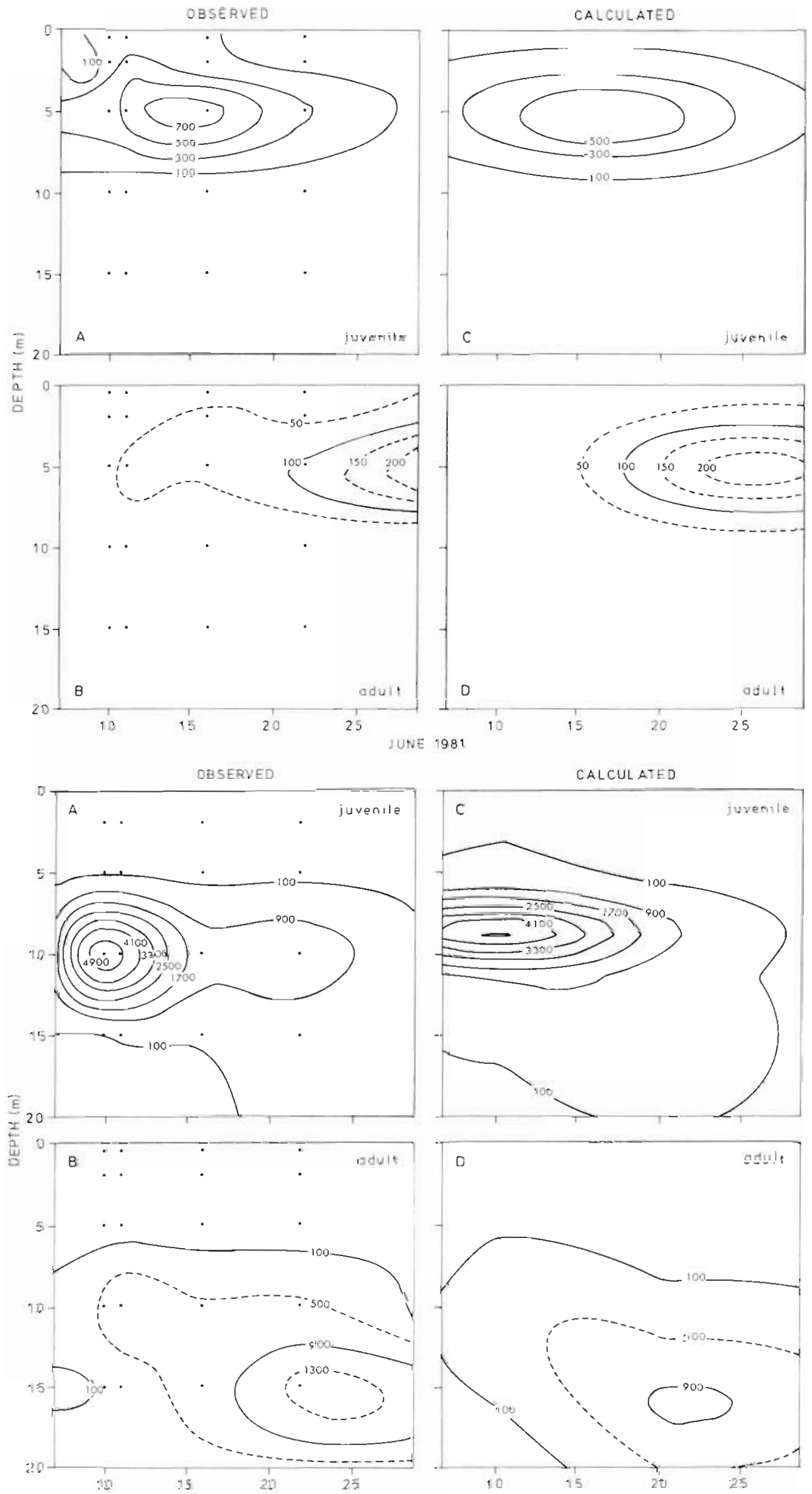

Fig. 5. Centropages hamatus. (A, B) Observed and (C, D) modelcalculated abundances (ind $\mathrm{m}^{-3}$ ) for (A, C) juvenile copepodids and (B, D) adults

Fig. 6. Pseudocalanus elongatus. $(A, B)$ Observed and $(C, D)$ model-calculated abundances (ind. $\mathrm{m}^{-3}$ ) for (A, C) juvenile copepodids and $(B, D)$ adults 
Fig. 7. Temora longicornis. (A, B) Observed and (C, D) model-calculated abundances (ind $\mathrm{m}^{-3}$ ) for $(A, C)$ juvenile copepodids and $(B, D)$ adults
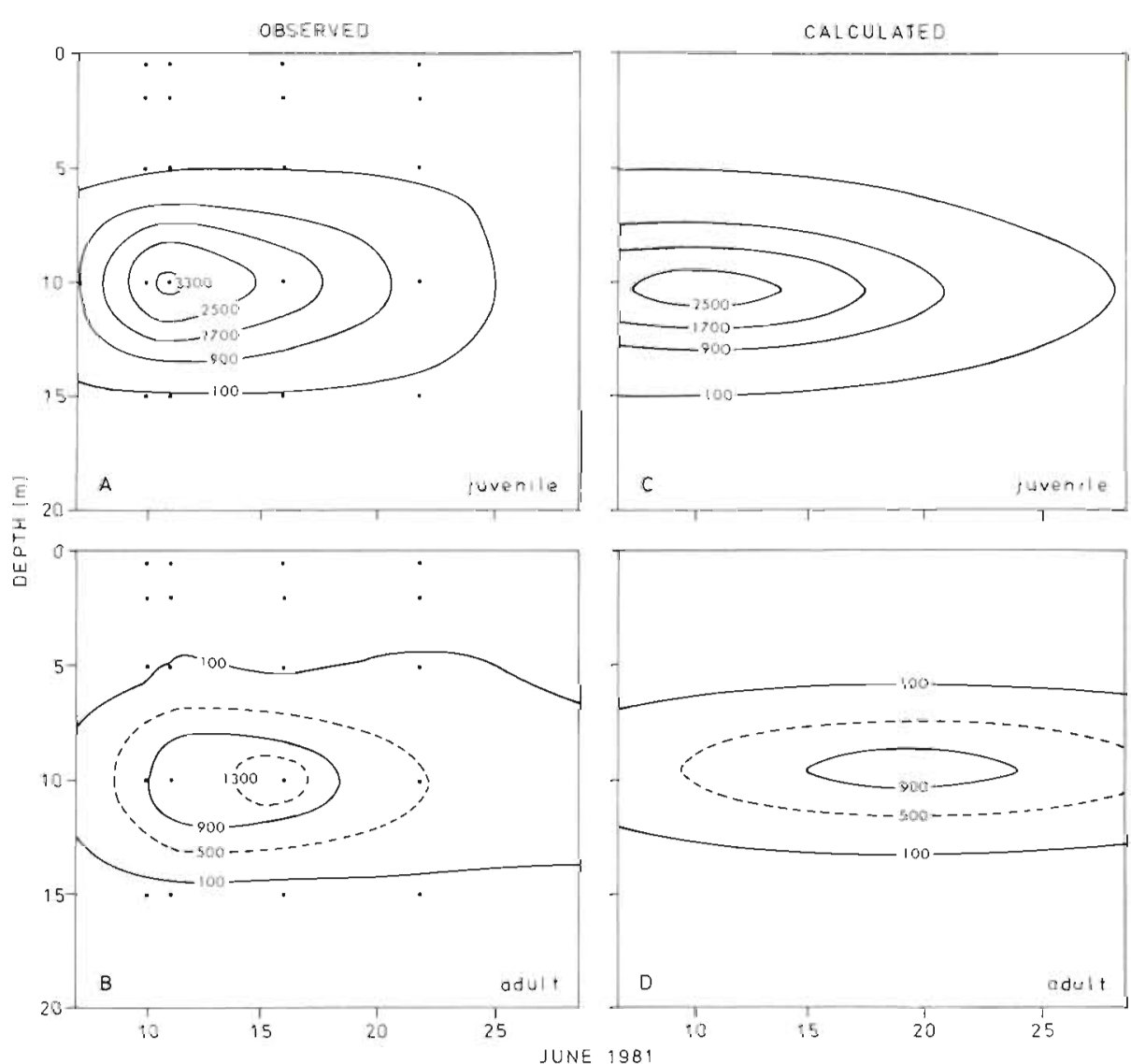

stages of $P$. elongatus (IV, $V$ and VI) occurred in increasing numbers at 15 and $20 \mathrm{~m}$ depth. This pattern may be interpreted as a result of a downward migration of the older copepodids. In the calculated time series a downward migration rate of $0.5 \mathrm{~m} \mathrm{~d}^{-1}$ was used for Stages IV, V and VI in the period from 11 to 22 June. The high numbers of juveniles found on 10 and 11 June were expressed by the model, but the model calculations did not correspond with the decrease in observed number of juveniles on 16 June. On this date a large part of the population may have been located between 10 and $15 \mathrm{~m}$ depth, where no samples were taken. This is consistent with the presumed downward migration of the older copepodid stages. The median stage value for the population corresponded to Copepodid $\mathrm{V}$ on 16 June (Fig. 2). At this time, the observed mean depth of the population was $12.7 \mathrm{~m}$, and a peak in numbers may have been located between the sampling depths. The variance between model calculations and observations was higher than the variance within observations for all 3 developmental groups (Table 2).

Temora longicornis. The maximum number of adults was found only $4 \mathrm{~d}$ after the maximum number of juveniles. High numbers of $T$. longicornis were, however, found only at $10 \mathrm{~m}$ depth during the investigation (Fig. 7), and as with Pseudocalanus elongatus more sampling depths close to $10 \mathrm{~m}$ would have given a more accurate picture of the time/depth distribution. Inadequate sampling is also reflected by the high variance found within observations during the daytime

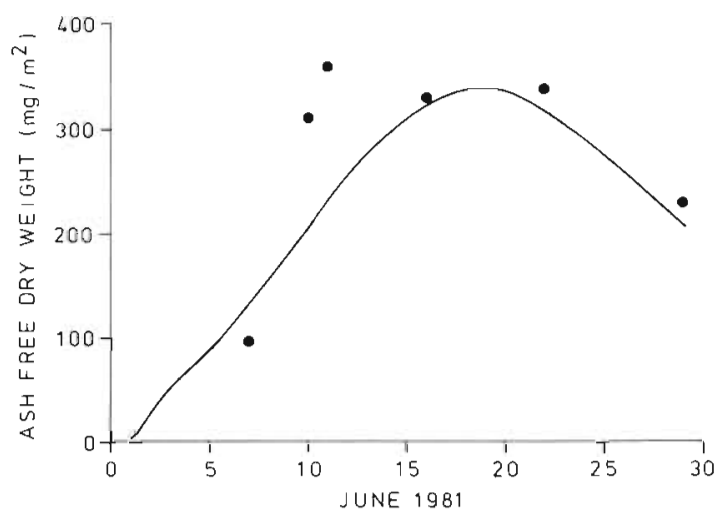

Fig. 8. Observed $(\bullet)$ and model-calculated $(-)$ surface-integrated biomass for the 4 calanoids

samples on 10 and 11 June. The variance between the model calculations and observations was in fact lower than the variance within observations for all 3 groups (Table 2). 

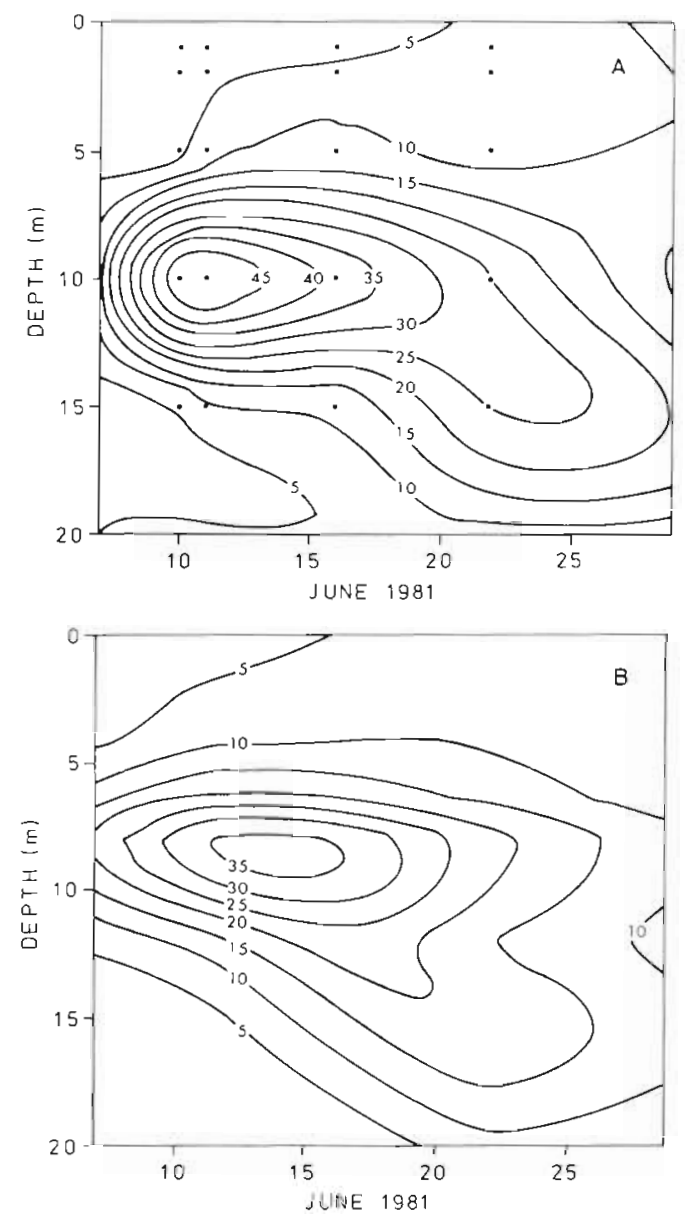

Fig. 9. (A) Observed and (B) model-calculated biomass (mg ash-free dry weight $\mathrm{m}^{-3}$ ) for the 4 calanoids

\section{Biomass, production and productivity}

The model-calculated biomass summed for all 4 species corresponds well with the 'observations' (counts multiplied by the corresponding ash-free dry

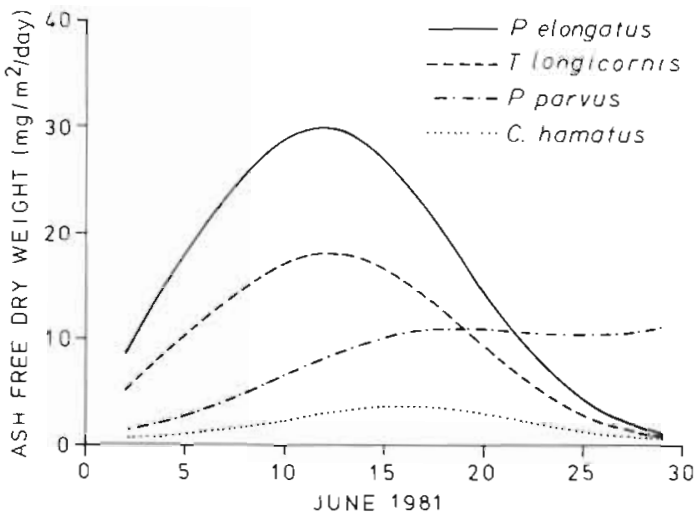

Fig. 10. Surface-integrated production for each of the 4 calanoids

weight values) on 7, 16, 22 and 29 June (Fig. 8). The calculated curve, however, does not express the high values observed on 10 and 11 June. These values are explained by the high abundances observed at $10 \mathrm{~m}$ depth on these dates (Fig. 9a). A fairly close agreement is found between model and observations above and below this depth (Fig. 9).

Production (Table 3) was calculated by assuming equal stage-specific survival ( $w$ ) within copepodid Stages I, II and III, and within Stages IV and V. Adults contributed more than $50 \%$ to the total production for each of the 4 species. Of the total calanoid copepod production of $992 \mathrm{mg}$ ash-free dry weight $\mathrm{m}^{-2}$, Pseudocalanus elongatus, Paracalanus parvus, Temora longicornis and Centropages hamatus contributes 45 , 26,23 and $6 \%$, respectively. Another calanoid, Acartia longiremis, was also represented in the samples (in the upper $5 \mathrm{~m}$ ), but due to low numbers and high variance, no estimates of population parameters are presented. Production, however, was estimated to be of the same order as for C. hamatus.

Estimated daily production was highest for the

Table 3. Cohort production ( $P$; $\mathrm{mg}$ ash-free dry weight $\mathrm{m}^{-2}$ per cohort), as calculated by Eq. (4), and average biomass ( $B$, mg ashfree dry weight $\mathrm{m}^{-2}$ ) during 7 to 29 June

\begin{tabular}{|c|c|c|c|c|c|c|}
\hline \multirow[t]{2}{*}{$\begin{array}{l}\text { Copepodid } \\
\text { stage }\end{array}$} & \multicolumn{2}{|c|}{$\begin{array}{c}\text { Paracalanus parvus } \\
\text { Cohort }\end{array}$} & \multirow[t]{2}{*}{$\begin{array}{l}\text { Pseudocalanus } \\
\text { elongatus }\end{array}$} & \multirow[t]{2}{*}{$\begin{array}{c}\text { Temora } \\
\text { Jongicornis }\end{array}$} & \multirow[t]{2}{*}{$\begin{array}{c}\text { Centropages } \\
\text { hamatus }\end{array}$} & \multirow[t]{2}{*}{ Total } \\
\hline & I & II & & & & \\
\hline I & 3 & 3 & 16 & 13 & 4 & 39 \\
\hline II & 5 & 3 & 22 & 12 & 5 & 47 \\
\hline III & 12 & 5 & 33 & 15 & 6 & 71 \\
\hline IV & 31 & 4 & 44 & 16 & 6 & 101 \\
\hline V & 45 & 5 & 63 & 26 & 9 & 148 \\
\hline VI & 127 & 9 & 268 & 149 & 33 & 586 \\
\hline P & 223 & 29 & 446 & 231 & 63 & 992 \\
\hline B & \multicolumn{2}{|c|}{33} & 179 & 77 & 19 & 308 \\
\hline $\mathrm{P} / \mathrm{B}$ & \multicolumn{2}{|c|}{6.8} & 2.5 & 3.0 & 3.3 & 3.2 \\
\hline
\end{tabular}




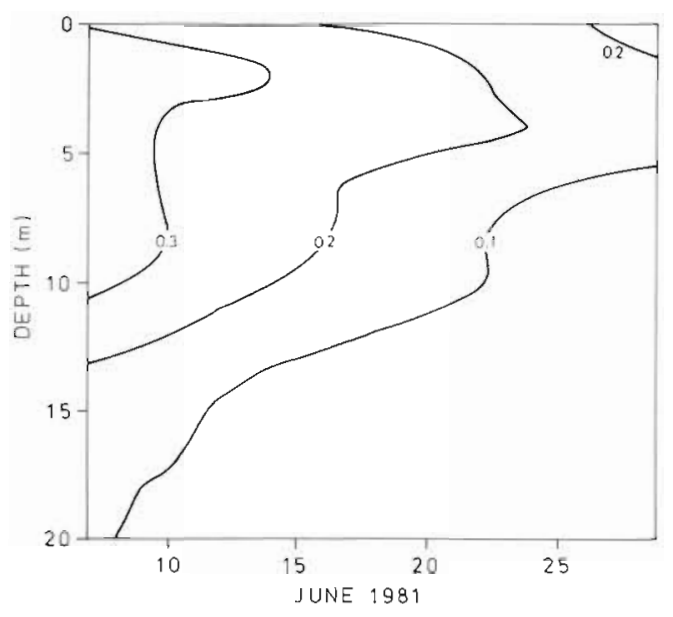

Fig. 11. Daily $\mathrm{P} / \mathrm{B}$ ratio of the 4 calanoids during the investigation

Pseudocalanus elongatus population in the first $20 \mathrm{~d}$ and successively lower for the Temora longicornis, Paracalanus parvus and Centropages hamatus populations (Fig. 10). As a result of the introduction of the second $P$. parvus cohort, the production of this population increased during the investigation. The ratio between estimated daily production and biomass for the 4 species was higher than 0.3 at the start of the investigation (Fig. 11). On average the daily $\mathrm{P} / \mathrm{B}$ ratio was highest in the upper $5 \mathrm{~m}$, and it decreased at all depths until about 25 June. The increase found near the surface at this time is explained by the introduction of the second $P$. parvus cohort. The cohort $\mathrm{P} / \mathrm{B}$ ratios (the ratio between the cohort production and the average biomass of the cohort) were in the range 2.5 to 6.8 (Table 3).

\section{DISCUSSION}

In a critique of current methods for the analysis of zooplankton cohort data, Hairston \& Twombly (1985) presented an argument for why widely used methods are incorrect under realistic field conditions, and thereby pointed out a need for new methods of cohort analysis. Our approach is an alternative computational procedure, relying on other assumptions (Aksnes \& Høisæter 1987) than those treated by Hairston \& Twombly (1985). We think that the present approach, which is essentially the same as that of Sonntag \& Parslow (1981), has potential in the analysis of secondary production dynamics. Our results show that the dynamics of the 4 species may be fairly well represented by the model given in Eq. (2) and the estimated parameters.

The methods used by Parslow et al. (1979) and Sonntag \& Parslow (1981) estimate the population parame- ters by means of curve-fitting (least square minimization) between model-calculated and observed abundances. Due to the high number of parameters incorporated in copepod population dynamics models, a much closer fit may be obtained between model calculations and observations than between 'replicate' observations. If a relatively large decrease is made in the mortality parameter $(\Theta)$, the fit between the model and the observations may remain unaltered (compared to the within-observation variance), if a simultaneous increase is made in the recruitment parameter $(M)$ together with adjustments in development time (a), mean time of entry to the stage $(\mu)$, and the temporal variance $(\sigma)$ of the recruitment function. Therefore, a close fit between model calculations and observations does not imply that the parameters are accurately estimated. Another pitfall with non-linear optimization algorithms is that they can fail to converge to a global minimum, either because they become trapped in some local minimum or because the convergence becomes too slow and expensive (Parslow et al. 1979).

Manly (1974b) found that a method relying on the estimated areas of the stage frequency curves (Kiritani \& Nakasuji 1967), rather than on curve-fitting between model predictions and observations (Manly 1974a, also used by Parslow et al. 1979), gave the most reliable estimates of stage-specific survival. Manly $(1976,1977)$ further developed this method. The estimates of recruitment, stage duration, and mortality obtained with the method of Manly (1977) are calculated from the stage frequency distributional statistics: the area and the temporal mean of the stage frequency curves. The model output obtained with this method (Figs. 4 to 9) is not a result of least square minimization between model calculations and observations, and the deviations between these (Table 2) are now a more satisfactory criterion of the estimation success. Several other estimation methods (Comita 1972, Rigler \& Cooley 1974, Gehrs \& Robertson 1975, Hairston \& Twombly 1985) are based on the same principle as the method of Manly (1977). The preferability of Manly's approach over the others is discussed by Aksnes \& Høisæter (1987).

The mortalities estimated in the present study (Table 1) are based upon a limited amount of data. As the accuracy of the estimated time series of abundances deteriorates, the use of 'known' development times in the estimation procedure may be preferable, and it may be questioned whether results from laboratory rearings should have been used in the present study. The other population parameters (including mortality) could then be estimated on the basis of these 'known' development times. In the following, however, we make a comparison between our estimates of development times and those obtained by others in laboratory rearing experiments. 


\section{Development times}

Development times obtained from laboratory experiments are likely to be precise, but they may be biased when extrapolated to natural populations. As pointed out by Davis (1983) there have been methodological problems associated with laboratory rearing experiments. The main objection is that, in addition to temperature, both quantity and quality of food may affect the development. Usually a monoculture or a few selected species of algae are chosen as food source for the presumably herbivorous species. Klein Breteler et al. (1982) suggested that quality of food was the most reasonable explanation for the difference between growth results from their own rearing experiments on Temora longicornis and Pseudocalanus elongatus and those of Paffenhöfer \& Harris (1976).

In the present study, the Paracalanus parvus and Centropages hamatus populations were exposed to temperatures of 12 to $14{ }^{\circ} \mathrm{C}$ (unpubl.). Bartram et al. (1976) observed a generation time for $P$. parvus of about $18 \mathrm{~d}$ at $18^{\circ} \mathrm{C}$ (in the laboratory). Close to this estimate, Landry (1983) obtained a generation time of $P$. parvus of $18.6 \mathrm{~d}$ at $15^{\circ} \mathrm{C}$ in his rearing experiments, and the development time from Copepodid I to VI amounted to about $9.5 \mathrm{~d}$. In natural populations, however, shorter development times have been obtained. Sonntag \& Parslow (1981) estimated the generation time of $P$. parvus as $12 \mathrm{~d}$ for 2 different cohorts developing in enclosures with a temperature range of 10.2 to $17.2^{\circ} \mathrm{C}$ (Harris et al. 1982). The development times for the combined Stages I to $\mathrm{V}$ were estimated as 6.80 and $6.82 \mathrm{~d}$ for the 2 cohorts, which are close to our estimate of $6.4 \mathrm{~d}$ (Table 1). Klein Breteler (1980) estimated the generation time of Centropages hamatus as $19.7 \mathrm{~d}$ in a laboratory experiment $\left(15^{\circ} \mathrm{C}\right)$, while our estimate of the combined development time of the Stages I to VI was $16 \mathrm{~d}$ (Table 1). There are discrepancies among the several estimates obtained from rearing experiments on Pseudocalanus elongatus and Temora longicornis (Katona \& Moodie 1969, Harris \& Paffenhöfer 1976, Paffenhöfer \& Harris 1976, Klein Breteler 1980, Vidal 1980, Thompson 1982, Davis 1983, Landry 1983). Our estimates (Table 1 ) are in best agreement with the experiments giving the shortest development times (Klein Breteler 1980, Landry 1983). Landry (1983) estimated a generation time of $18.6 \mathrm{~d}\left(15^{\circ} \mathrm{C}\right)$ and a combined development time for Stages I to $\mathrm{V}$ of $9.8 \mathrm{~d}$ for Pseudocalanus sp., while our estimate was $9.2 \mathrm{~d}$ (Table 1). Klein Breteler (1980) gave no estimate for the development times of the copepodids, but he estimated the generation time of $T$. longicornis to be about $21 \mathrm{~d}$ $\left(15^{\circ} \mathrm{C}\right)$.

From the above discussion, one may conclude that our estimates of development times are in fairly good agreement with the shorter development times obtained in laboratory experiments. A choice of using 'known' values of development times (instead of estimating them, as we did), would therefore have led to estimates of the other population parameters not very different from those presented in Table 1.

\section{Production and biomass}

The estimated $\mathrm{P} / \mathrm{B}$ ratios were in the range 2.5 to 6.8 per cohort (Table 3). The ratio for Paracalanus parvus was 2.1 to 2.7 times higher than the rate for the other species. Within species, it has been shown that copepod growth rates decrease with increasing stage and weight (Harris \& Paffenhöfer 1976, Paffenhöfer \& Harris 1976, Vidal 1980). According to this, the productivity potential of a population is highest for the population composed of the youngest individuals. Due to higher mortality and higher recruitment (Table 1) the median stage value of $P$. parvus was, on average, lower than for the other species (Fig. 2), and this may explain the high productivity of $P$. parvus. Furthermore, $P$. parvus was exposed to a higher temperature than the other species, and was located at the primary production maximum (see below). These conditions may also have increased the productivity.

There has been a controversy whether the $\mathrm{P} / \mathrm{B}$ ratio of copepods is mass-specific or not (Banse 1984, McLaren \& Corkett 1984, Roff \& Tremblay 1984). McLaren \& Corkett (1984) claimed that the $\mathrm{P} / \mathrm{B}$ ratio among copepods is not mass-specific, and criticized the way Tremblay \& Roff (1983) estimated copepod production. The estimated daily $P / B$ ratio (obtained by a combination of Eq. [5] and biomass data) against the observed median stage of the populations is plotted in Fig. 12.

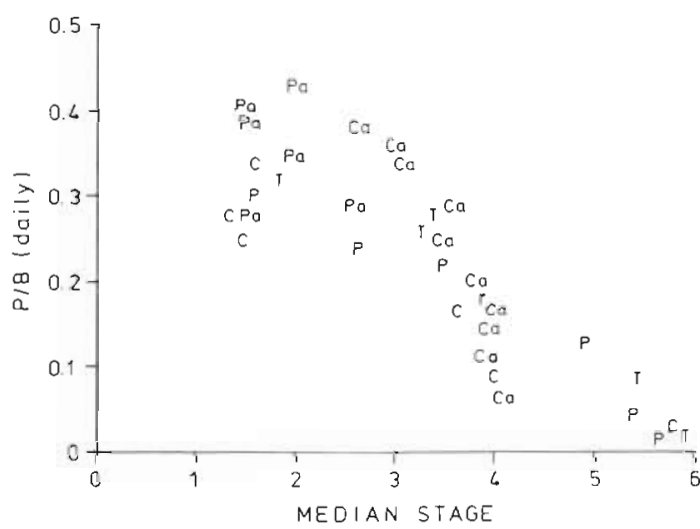

Fig. 12. Daily P/B ratios plotted against observed median stage. Pa: Paracalanus parvus; C: Centropages hamatus; P: Pseudocalanus elongatus; T: Temora longicornis; Ca: Calanus finmarchicus. Data for C. finmarchicus obtained from an investigation in Lindåspollene in 1979 (Aksnes \& Magnesen 1983) 


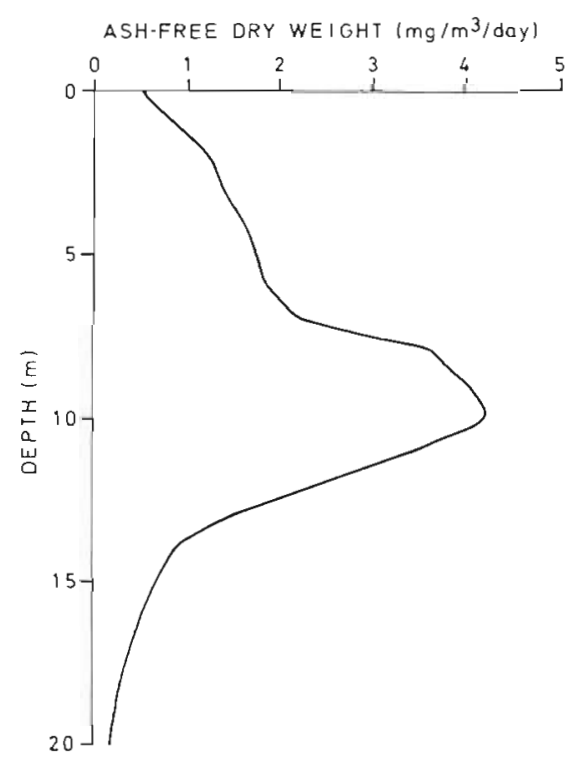

Fig. 13. Model-calculated production for the 4 calanoids as a function of depth. Production is represented as an average for the period 7 to 29 June

There seems to be a relationship between the size of the animal and the daily $\mathrm{P} / \mathrm{B}$ ratio within a species, but not between the 5 species. The daily $\mathrm{P} / \mathrm{B}$ ratios for the large copepod, Calanus finmarchicus (values calculated from Aksnes \& Magnesen 1983), are comparable to those found for the small $P$. parvus. These limited data seem to support the conclusion of McLaren \& Corkett (1984) that $\mathrm{P} / \mathrm{B}$ ratios among copepods are not mass-specific. An examination of annual P/B ratios, however, would probably led to the opposite conclusion since $C$. finmarchicus had only one cohort during the year (Aksnes \& Magnesen 1983), while several cohorts are reported for the other calanoids (Ellingsen 1973, Hassel 1980). As pointed out by Banse (1984) the time period underlying the $\mathrm{P} / \mathrm{B}$ estimates is therefore of vital importance when comparing turnover times among different species.

From ${ }^{14} \mathrm{C}$ incubations (performed every second or third day during the investigation) it was found that $70 \%$ of the primary production was confined to the upper $5 \mathrm{~m}$ of the water column (H. R. Skjoldal pers. comm.). The highest daily productivity of the 4 calanoids was also found in this part of the water column (Fig. 11), while the total calanoid production was highest at $10 \mathrm{~m}$ depth (Fig. 13). From a mesocosm experiment in Lindåspollene during June 1979, Skjoldal et al. (1983) suggested that the mesozooplankton could apparently not explain the high mineralization rate in the uppermost $5 \mathrm{~m}$ where most of the photosynthetic activities took place (in that study $70 \%$ of ${ }^{14} \mathrm{C}$-fixation took place in the top $4.5 \mathrm{~m}$ ). The mesozooplankton was mainly distributed below this photosyn- thetically important surface layer. Temora longicornis was the dominant herbivore copepod in their study and this species was, as in the present study, virtually absent from the surface layer. Calculations of the supply of 'new nutrients' into the surface layer from the nutricline due to turbulent diffusion showed that less than $20 \%$ of the carbon fixation could be explained by this input (Skjoldal et al. 1983). They concluded that other organisms (e.g. bacteria, heterotrophic flagellates and ciliates) than those included in their study had to be responsible for the high mineralization and photosynthetic activity in the surface layer. During the present investigation the highest calanoid biomass was also found at $10 \mathrm{~m}$ depth (Fig. 9a) and the small vertical migrations detected among the mesozooplankton (Lie et al. 1983) reinforce the impression of small direct interactions between the most active photosynthetic layer and the layer with the highest mesozooplankton production. Furthermore, the presumed downward movement of late copepodids and adults of Pseudocalanus elongatus (Fig. 6), resulted in an export of organic matter from the photic zone (Fig. 9). Paracalanus parvus and Centropages hamatus, however, must have been part of an active consumptionremineralization relationship within the main phytoplankton productive layer.

Acknowledgements. We gratefully appreciate the critique and comments to the manuscript from U. Lie and T Høisæter, Department of Marine Biology, and from H. R. Skjoldal, Institute of Marine Research, and our thanks are due to E. Holm who made the line drawings. This research was supported by a grant from the Norwegian Council for Science and the Humanities.

\section{LITERATURE CITED}

Aksnes, D. L., Høisæter, T. (1987). Obtaining life table data by using stage frequency distributional statistics. Limnol. Oceanogr. 32: 514-517

Aksnes, D. L., Magnesen, T (1983). Distribution, development, and production of Calanus finmarchicus (Gunnerus) in Lindåspollene, western Norway, 1979. Sarsia 68: 195-208

Ashford, J. R., Read, K. L. Q., Vickers, G. G. (1970). A system of stochastic models applicable to studies of animal population dynamics. J. Anim. Ecol. 39: 29-50

Banse, K. (1984). Reply. Can. J. Fish. aquat. Sci. 41: 833-834

Bartram, W. C., Chekley, D. M., Heinbokel, J. F. (1976). Further use of a deep tank in the study of the planktonic food chain. Inst. Mar. Res. Univ. Calif. IMR Ref. 76-7: $157-166$

Birley, M. (1977). The estimation of insect density and instar survivorship functions from census data. J. Anim. Ecol. 46: $497-510$

Comita, G. W (1972). The seasonal zooplankton cycles, production and transformations of energy in Severson Lake, Minnesota. Arch. Hydrobiol. 70: 14-66

Davis, S. D. (1983). Laboratory rearing of marine calanoid copepods. J. exp. mar. Biol. Ecol. 71: 119-133 
Ellingsen, E. (1973). Kvantitative og kvalitative zooplankton undersokelser i Lindåspollene. Cand. real. thesis, Univ. Bergen

Fager, E. W. (1973). Estimation of mortality coefficients from field samples of zooplankton. Limnol. Oceanogr. 18: 297-301

Gehrs, C. W., Robertson, A. (1975). Use of life tables in analyzing the dynamics of copepod populations. Ecology 56: $665-672$

Hairston, N. G., Twombly, S. (1985). Obtaining life table data from cohort analyses: a critique of current methods. Limnol. Oceanogr. 30: 886-893

Hairston, N. G., Braner, M., Twombly, S. (1987). Perspective on prospective methods for obtaining life table data. Limnol. Oceanogr 32: 517-520

Harris, R. P., Paffenhöfer, G.-A. (1976). Feeding, growth and reproduction of the marine planktonic copepod Temora longicornis Muller. J. mar. biol. Ass. U.K. 56: 675-690

Harris, R. P., Reeve, M. R., Grice, G. D., Evans, G. T., Gibson, V R., Beers, J. R., Sullivan, B. K. (1982). Trophic interactions and production processes in natural zooplankton communities in enclosed water columns. In: Grice, G. D., Reeve, M. R. (eds.) Marine mesocosms. Springer Verlag, New York, p. 353-388

Hassel, A. (1980). Populasjonsdynamikk hos Pseudocalanus elongatus (Boeck) i Lindåspollene. Cand. real. thesis, Univ. Bergen

Katona, S. K., Moodie, C. F. (1969). Breeding of Pseudocalanus elongatus in the laboratory. J. mar biol. Ass. U.K. 49: 743-747

Kempton, R. A. (1979). Statistical analysis of frequency data obtained from sampling an insect population grouped by stages. In: Ord, J. K., Patil, G. P., Taillie, C. (eds.) Statistical distributions in ecological work. Fairland, Maryland, p. $401-418$

Kiritani, K., Nakasuji, F. (1967). Estimation of the stage specific survival rate in the insect population with overlapping stages. Res. Pop. Ecol. 9: 143-152

Klein Breteler, W. C. M. (1980). Continuous breeding of marine pelagic copepods in the presence of heterotrophic dinoflagellates. Mar. Ecol. Prog. Ser. 2: 229-233

Klein Breteler, W. C. M., Fransz, H. G., Gonzalez, S. R. (1982). Growth and development of four calanoid copepod species under experimental and natural conditions. Neth. J. Sea Res. 16: 195-207

Landry, M. R. (1983). The development of marine calanoid copepods with comments on the isochronal rule. Limnol. Oceanogr. 28: 614-624

Lie, U., Magnesen, T., Tunberg, B., Aksnes, D. (1983). Preliminary studies on the vertical distribution of size-fractions in the zooplankton community in Lindaspollene, western Norway. Sarsia 68: 65-80

Lynch, M. (1983). Estimation of size specific mortality rates in zooplankton populations by periodic sampling. Limnol. Oceanogr. 28: 533-545
Manly, B. F. J. (1974a). Estimation of stage-specific survival rates and other parameters for insect populations developing through several stages. Oecologia (Berl.) 15: 277-285

Manly, B. F. J. (1974b). A comparison of methods for the analysis of insect stage-frequency data. Oecologia (Berl.) 17: $335-348$

Manly, B. F. J. (1976). Extensions to Kiritani and Nakasuji's method for analysing insect stage frequency data. Res. Pop. Ecol. 17: 191-199

Manly, B. F. J. (1977). A further note on Kiritani and Nakasuji's model for stage frequency data including comments on the use of Tukey's jackknife technique for estimating variances. Res. Pop. Ecol. 18: 177-186

McLaren, I. A., Corkett, C. J. (1984). Singular, mass-specific $\mathrm{P} / \mathrm{B}$ ratios cannot be used to estimate copepod production. Can. J. Fish. aquat. Sci. 41:828-830

Motoda, S. (1959). Devices of simple plankton apparatus. Mem. Fac. Fish. Hokkaido Univ. 7: 73-94

Paffenhöfer, G.-A., Harris, R. P. (1976). Feeding, growth and reproduction of the marine planktonic copepod $P_{\text {seudo- }}$ calanus elongatus Boeck. J. mar. biol. Ass. U.K. 56: $327-344$

Parslow, J., Sonntag, N. C., Matthews, J. B. L. (1979). Technique of system identification applied to estimating copepod population parameters. J. Plankton Res. 1: $137-151$

Richards, O. W., Waloff, N., Spradberry, J. P. (1960). The measurement of mortality in an insect population which recruitment and mortality widely overlap. Oikos 11: 306-310

Rigler, F. H., Cooley, J. M. (1974). The use of field data to derive population statistics of multivolitine copepods. Limnol. Oceanogr. 19: 636-655

Roff, J. C., Tremblay, M. J. (1984). Reply with additional notes on P/B ratios. Can. J. Fish. aquat. Sci. 41: 830-833

Skjoldal, H. R., Johannessen, P., Klinken, J., Haldorsen, H (1983). Controlled ecosystem experiment in Lindåspollene, western Norway, 1979: comparisons between the natural and two enclosed water columns. Sarsia 68: 47-64

Sonntag, C. S., Parslow, J. (1981). Technique of system identification applied to estimating copepod production. J. Plankton Res. 3: 461-473

Straalen, N. M. van (1982). Demographic analysis of arthropod populations using a continuous stage-variable. J. Anim. Ecol. 51: 769-783

Thompson. B. M. (1982). Growth and development of Pseudocalanus elongatus and Calanus sp. in the laboratory. J mar. biol. Ass. U.K. 62: 359-372

Tremblay, M. J., Roff, J. C. (1983). Production estimates for Scotian Shelf copepods based on mass specific P/B ratios. Can. J. Fish. aquat. Sci. 40: 749-753

Vidal, J. (1980). Physioecology of zooplankton. II. Effects of phytoplankton concentration, temperature, and body size on the growth rate of Calanus pacificus and Pseudocalanus sp. Mar. Biol. 56: 111.-134 